\title{
THE NEW REDUCED EYE ADAPTED TO ACCOMMODATION
}

BY

\author{
V. C. Verbitzky,
}

ASSISTANT IN THE OPHTHALMIC CLINIC, UNIVERSITY OF ODESSA.

IN my recent publications ${ }^{1}$ and ${ }^{2}$, I have attempted to present ja $^{3}$ reduced eye, differing essentially in principle of construction from all others hitherto offered. I have composed the following system of equations, according to the exact schematic eye of Gullstrand ${ }^{3}$ :-

$$
\begin{array}{ll}
\text { Refractive power } \frac{\mathrm{n}-1}{\mathrm{R}}=58.64 \mathrm{D} . & . \quad \\
\text { Spherical aberration } \frac{3.2^{2}}{8 \mathrm{n}(\mathrm{n}-1) \mathrm{R}}=0.387 \mathrm{~mm} . & \text { II. }
\end{array}
$$

From these the constants of the reduced eye are determined: $\mathrm{R}=6.8 \mathrm{~mm}$., and $\mathrm{n}=1.4$. The values are much higher than the constants of the generally used reduced eyes of Listing ${ }^{4}$, Donders ${ }^{5}$ and Gullstrand ${ }^{3}$, but they are less than the constants of von Hasner ${ }^{6}$. Thus my reduced eye occupies the middle place. The following

\begin{tabular}{|c|c|c|c|c|c|c|c|c|c|}
\hline & \multirow{2}{*}{$\begin{array}{c}\text { Sche- } \\
\text { matic } \\
\text { eye of } \\
\text { Gull- } \\
\text { strand. }\end{array}$} & \multicolumn{2}{|c|}{$\begin{array}{l}\text { Reduced eye } \\
\text { of Donders. }\end{array}$} & \multicolumn{2}{|c|}{$\begin{array}{c}\text { Reduced eye } \\
\text { of Hasner. }\end{array}$} & \multicolumn{2}{|c|}{$\begin{array}{l}\text { Reduced eye } \\
\text { of Gullstrand. }\end{array}$} & \multicolumn{2}{|c|}{$\begin{array}{l}\text { Reduced eye } \\
\text { of Verbitzky. }\end{array}$} \\
\hline & & & $\begin{array}{c}\text { Error } \\
\text { in \% \% }\end{array}$ & & $\begin{array}{c}\text { Error } \\
\text { in } \% \%\end{array}$ & & $\begin{array}{l}\text { Error } \\
\text { in \% \% }\end{array}$ & & $\begin{array}{l}\text { Error } \\
\text { in \% \% }\end{array}$ \\
\hline Refractive power... & $58.64 \mathrm{D}$ & 66.67 & 13.7 & 66.67 & 13.7 & 58.48 & 0.3 & 58.82 & 0.3 \\
\hline $\begin{array}{l}\text { Astigmatism of } \\
\text { oblique incidence } \\
\left(\text { at } \angle a=5^{\circ}\right)\end{array}$ & $0.086 \mathrm{D}$ & 0.104 & 20.9 & 0.083 & 3.5 & 0.092 & 7.0 & 0.084 & 2.3 \\
\hline $\begin{array}{l}\text { Spherical aberration } \\
\text { (at } r=2 \mathrm{~mm} \text {.) }\end{array}$ & $1.0 \mathrm{D}$ & 2.33 & 133.0 & 0.80 & 20.0 & 1.56 & 56.0 & 0.99 & 1.0 \\
\hline Length of the eye... & $\begin{array}{r}24.0 \mathrm{~mm} \\
7.7 \mathrm{~mm}\end{array}$ & $\begin{array}{r}19.3 \\
5.0\end{array}$ & $\begin{array}{l}19.6 \\
35.1\end{array}$ & $\begin{array}{r}22.2 \\
7.5\end{array}$ & $\begin{array}{l}7.5 \\
2.6\end{array}$ & $\begin{array}{r}22.2 \\
5.7\end{array}$ & $\begin{array}{r}7.5 \\
26.0\end{array}$ & $\begin{array}{r}23.4 \\
6.8\end{array}$ & $\begin{array}{r}2.5 \\
11.7\end{array}$ \\
\hline $\begin{array}{l}\text { Radius of curvature } \\
\text { of the corneal } \\
\text { surface }\end{array}$ & $7.7 \mathrm{~mm}$ & & & & & & & & \\
\hline $\begin{array}{l}\text { Radius of curvature } \\
\text { of the retinal } \\
\text { surface }\end{array}$ & $10.5 \mathrm{~mm}$ & 8.4 & 20.0 & 9.7 & 7.6 & 9.7 & 7.6 & 10.2 & 2.9 \\
\hline
\end{tabular}
table shows the advantages of my reduced eye :- -

In the present work I shall try to adapt the reduced eye to accommodation. In the drawing is represented the contour (optical) of the reduced eye. In order that such an eye shall closely correspond to the schematic eye it must possess coincidence of its contours and equality of its angles. For the exact schematic eye of Gullstrand ${ }^{7}$ it is known that $\mathrm{DC}=4.757 \mathrm{~mm}$. at rest and $=5.136 \mathrm{~mm}$. at maximal accommodation. Then, taking into consideration that the radius of curvature of cornea $R$ remains without change in the 
schematic. eye in accommodation, we deduce from the formula $\sin \varphi=\frac{\mathrm{DC} \sin \alpha}{\mathrm{R}}$ for the middle $\angle \alpha$ at $5^{\circ}$ two values of the $\angle \varphi$ : $3.045^{\circ}$ at rest and $3.288^{\circ}$ at maximal accommodation. Further, applying the known coefficient of augmentation in diaphragms for the schematic eye of Gullstrand ${ }^{7} \mathrm{~K}=0.909$ at rest and $\mathrm{K}=0.941$ at maximal accommodation from the formula $\mathrm{K}=\frac{\mathrm{n} \tan \alpha}{\mathrm{n}, \tan \pi, \mathrm{n}^{\prime} \omega}$ [where $\alpha=5^{\circ}, \mathrm{n}($ air $)=1, \mathrm{n}^{\prime}$ (vitreous humour) $=1.336$ ] we shall

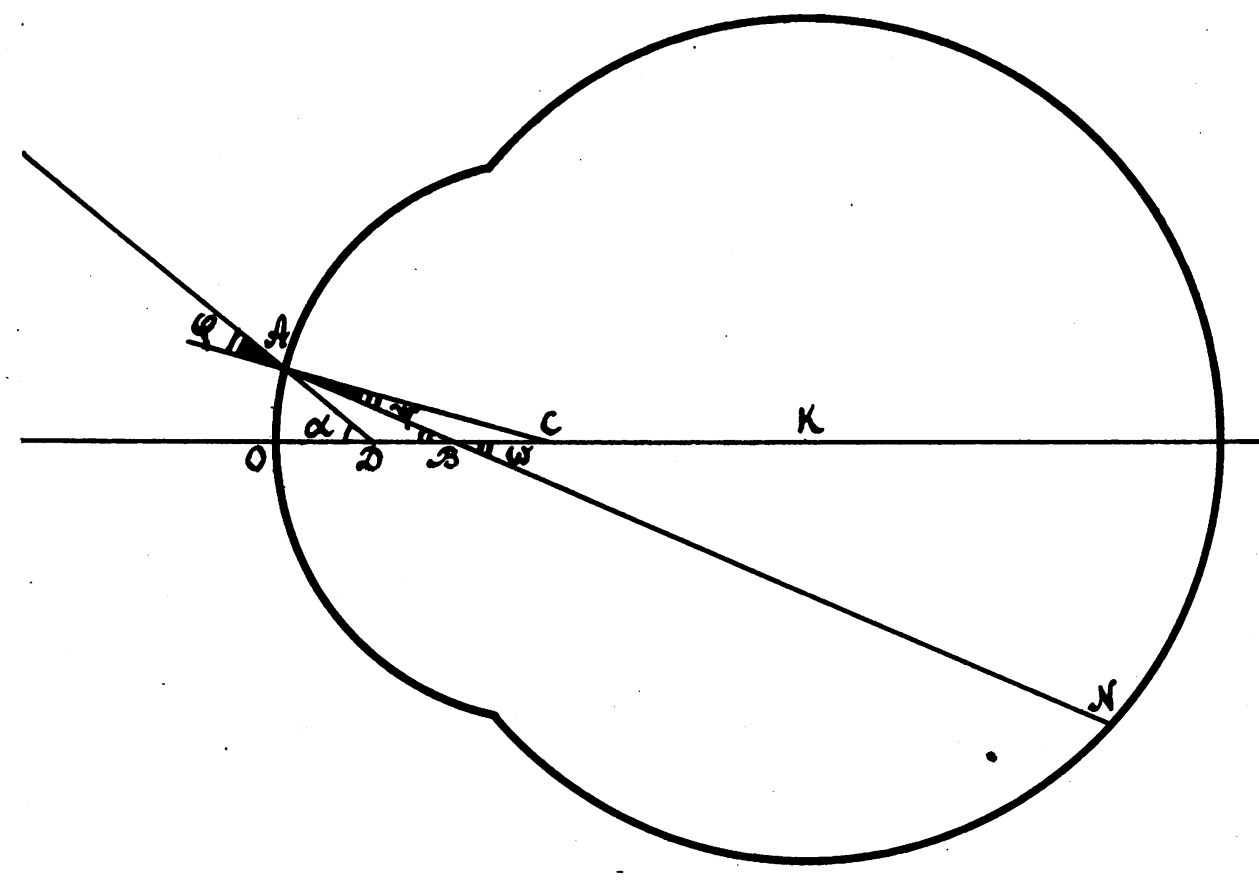

obtain for the angle $\omega$ two values: $4.121^{\circ}$ and $3.981^{\circ}$. From the correlation $a-\phi=\omega-\psi$ we shall have the $\angle \psi$ the two values: $2.166^{\circ}$ and $2.269^{\circ}$. But, since $\mathrm{n}=\frac{\sin \varphi}{\sin \psi}$ we determine two values for the index of refraction : 1.4057 and 1.4487 at rest and at maximal accommodation. In the schematic eye of Gullstrand ${ }^{3}$ the maximal accommodation $=10.6 \mathrm{D}$. Then the change of $\mathrm{n}$ by 1 dioptre of accommodation $=\frac{1.4487-1.4507}{10.6}=0.00406$, or, taking the round figure, $\Delta \mathrm{n}=0.004$.

The refractive power of the reduced eye proposed by me $=58.82 \mathrm{D}$, at maximal accommodation $=58.82+10.6=69.42$. Hence, by 
the formula $D=\frac{n-1}{R}=\frac{0.4+0.004-10.6-1}{R}=69.42$ we shall find $R=6.373 \mathrm{~mm}$. The radius of curvature changes from 6.8 to 6.373 . On each one dioptre the change will be $\frac{0.427}{10.6}=0.04028$, or $\triangle \mathrm{R}=0.04 \mathrm{~mm}$.

Thus we obtain the following simple rule:-For every dioptre of accommodation of the reduced eye the index of refraction $\mathrm{n}$ increases by 0.004 and the radius of curvature $\mathrm{R}$ diminishes by $0.04 \mathrm{~mm}$. How satisfactory is the effect of accommodation in this reduced eye will be seen in the following table:-

\begin{tabular}{c|c|c|c|c|c|c}
\hline $\begin{array}{c}\text { Accommo- } \\
\text { dation. }\end{array}$ & $\mathrm{R}$ & $\mathrm{n}$. & $\begin{array}{c}\mathrm{D} \\
\text { it must be. }\end{array}$ & $\begin{array}{c}\mathrm{D} \\
\text { in reality. }\end{array}$ & $\begin{array}{c}\text { Difference. } \\
\text { Error of } \\
\text { the acom- } \\
\text { modation } \\
\text { in \% \% }\end{array}$ \\
\hline & & & & & & \\
\hline $\mathrm{OD}$ & $\mathrm{mm}$. & & & & & \\
1 & 6.80 & 1.400 & 58.8 & 58.8 & 0 & 0 \\
2 & 6.76 & 1.404 & 59.8 & 59.8 & 0 & 0 \\
3 & 6.72 & 1.408 & 60.8 & 60.7 & -0.1 & 5 \\
4 & 6.68 & 1.412 & 61.8 & 61.7 & -0.1 & 3 \\
5 & 6.64 & 1.416 & 62.8 & 62.6 & -0.2 & 5 \\
6 & 6.60 & 1.420 & 63.8 & 63.6 & -0.2 & 4 \\
7 & 6.56 & 1.424 & 64.8 & 64.6 & -0.2 & 3 \\
8 & 6.52 & 1.428 & 65.8 & 65.6 & -0.2 & 3 \\
9 & 6.48 & 1.432 & 66.8 & 66.7 & -0.1 & 1 \\
10 & 6.44 & 1.436 & 67.8 & 67.7 & -0.1 & 1 \\
11 & 6.40 & 1.440 & 68.8 & 68.8 & 0 & 0 \\
12 & 6.36 & 1.444 & 69.8 & 69.8 & 0 & 0 \\
\hline
\end{tabular}

Whether my rule for the accommodated reduced eye is the most suitable one, or some other correlation would be better, will be seen in further works. But the numberless problems of accommodation which require solution denote persistently, I think, the necessity of the construction of an accommodated reduced eye.

\section{LITERATURE}

1. Verbitzky, V.- "The New Attempt of the Simplification of the Optical System of the Eye." The Review of the Pure and Applied Science, Odessa, 1921. (Russian.)

2. Verbitzky, V.- "Zur Frage von den schematischen und reduzierten Augen." Klin. Monatsbl. f. Augenheilk., Vol. LXVIII, 1922.

3. Gullstrand, A.- "Zusätze im Handb. d. physiol. Optik. v. Helmholtz's." 3 Aufl., 1909.

4. Helmholtz. H. v.--"Handbuch d. physiolog. Optik." 2 Aufl., 1896.

5. Donders. F.- "On the Anomalies of Accommodation and Refraction of the Eye," 1864.

6. Hasner, v.- “ Über das reduzierte Auge." Arch.f. Augen. u. Ohrenheilkunde, Vol. VII, 1878.

7. Rohr, M. - "Zur Dioptrik des Anges." Asher u. Spiro. Ergebnisse d. Physiologie, Vol. VIII, 1909. 